4. YAKOVLEV, P. P. (2017) Effekt Trampa» ili Konets globalizatsii?: monogr. - Moskva: RUSAYNS.

5. YAKOVLEV, P. P. (2016) Prezidentstvo B. Obamyi: predvaritelnyie itogi [Online] Available from:

http://www.perspektivy.info/oykumena/amerika/prezidentstvo_b_obamy_predvaritelnyje_itogi_2016-0829.htm (Accessed December 8, 2017).

6. WEEKS G. (2017) The Trump Doctrine in Latin America [Online] Available from: https://theglobalamericans.org/2017/08/trump-doctrine-latin-america/ (Accessed December 8, 2017).

7. WILKINSON, S. A (2017) Perfect Impasse? Cuba's Move towards the Market and the United States" Move Towards Cuba S. Economic Affairs. Vol. 37. №. 1. P. 19-35.

Надійшла до редколегії 15.04.2018

Kateryna Vakarchuk, $\mathrm{PhD}$ in Political Sciences, Associate professor Odessa I. I. Mechnicov National University

\title{
POLICY OF THE D. TRUMP ADMINISTRATION IN LATIN AMERICAN COUNTRIES: PREDICTION AND PROSPECTS
}

\begin{abstract}
The article discusses the main changes of US foreign policy towards Latin American countries under the administration of D.Tramp. The new challenges and approaches to establishing relations between the countries of the Western countries are analyzed. A main visit to the countries of Latin America is considered by the representatives of the new administration of the USA, in particular Colombia, Argentina, Chile and Panama. Key issues of developing a common position on the crisis in Venezuela and the possibility of US military intervention on security issues, improving trade and economic cooperation and restoring democracy in Latin America.

The statements of analysis regarding the change of US policy towards Mexico relates to the construction of a new border in the form of a wall between two countries, the strengthening of measures on migration policy, the revision of the North American Free Trade Agreement and the positions of Mexico and Canada. The establishment of diplomatic relations between Cuba and the United States was met D. Tramp's critics. He said that he wouldn't continue to declare strategy of his predecessor until the leadership, the political regime of the Cuba and the restoration of the rights and freedoms of citizens will change on the island.

Change in the relations between Argentina and the US in connection with the arrival of the new president of Argentina, official visits between the presidents of both countries took place. As for Venezuela, the most urgent issue is because the United States seeks support from the continent's leaders for possible military intervention.
\end{abstract}

Key words: US, Latin America, foreign policy, relations, prospects

УДК 94:327.8 (73+729.1) «1959»

http://doi.org/10.17721/2521-1706.2018.05.169-179

Катерина Касаткіна, аспірантка,

Запорізький національний університет

\section{СТАВЛЕННЯ ВАШИНГТОНУ ДО ПІСЛЯРЕВОЛЮЦЙНОЇ КУБИ (ПЕРШІ МІСЯЦ 1959 Р.)}

Анотація. У статті здійснена спроба проаналізувати ставлення Вашингтону до післяреволюиійної Куби у перші місяиі 1959 р. Окрім изього, представлена узагальнююча характеристика револючійних подій 1953 - 1959 рр., які вплинули на позицію Сполучених Штатів щэодо нового кубинського уряду. Проведено аналіз ключових проблем, які несли 
загрозу відновленню американсько-кубинських відносин в означений період. Розглянуто роль дипломатичних чинників як інструментів зовнішньої політики. Висвітлена аналітична робота американських дипломатів щчодо налагодження ефективної співпраці між Вашингтоном і Гаваною у перші місяиі 1959 р. Проаналізовано роль Ф. Кастро, як лідера кубинського революиійного руху та ключової сили в американсько-кубинських відносинах.

У результаті проведеного дослідження автор дійшов висновку, щзо позиція Вашингтону щеодо післяреволючійної Куби на самому початку 1959 р. була вичікувальною. Але, в цілому, прихильність Сполучених Штатів до традиційних патерналістських підходів у формуванні кубинського напрямку своєї зовнішньої політики негативно вплинула на встановлення діалогу з новим кубинським урядом, тож спроби налагодити взаєморозуміння, здійснені упродовж перших місяиів після револючії виявилися невдалими.

Ключові слова: США, Куба, Кубинська револючія, дипломатія, Ф. Кастро.

Упродовж останніх років в американо-кубинських взаєминах відбулися суттєві зміни, які розпочалися 3 відновлення дипломатичних відносин між країнами i, здавалося, могли б покласти кінець затяжному конфлікту між ними. Вагомий прогрес у нормалізації американсько-кубинських відносин був досягнутий адміністрацією президента Б. Обами. В його оновленому курсі щодо Куби був запланований комплекс заходів, спрямованих на закріплення позитивних тенденцій у зближенні Вашингтона і Гавани. Проте, нова адміністрація Д. Трампа не підтримала оновленого американського курсу щодо Куби i поквапилася покласти край змінам, започаткованим попереднім президентом. Відмова від курсу Б. Обами викликала чергове загострення відносин між двома країнами, демонструючи повернення Сполучених Штатів до традиційних підходів не тільки у кубинському напрямку своєї політики, але і загалом щодо латиноамериканського регіону.

Враховуючи актуальність вивчення нового етапу трансформації взаємин між США і Кубою, слід визнати, що для кращого розуміння його особливостей необхідно звернутися до дослідження передумов виникнення американськокубинського конфлікту i аналізу політики Вашингтону у перші роки після Кубинської революції 1959 р.

Вивчення політики США щодо післяреволюційної Куби неодноразово ставало предметом дослідницького інтересу вчених. Це підтверджується чималою кількістю робіт, що вийшла за цією тематикою. Більшу частину таких досліджень складають роботи істориків, які вивчали цю проблему у рамках конфлікту взаємин між США та Кубою у другій половині XX - початку XXI ст., серед них: Е. Домінгес [1], Л. Перес [2], Д. Сенз [3], або через призму наслідків Кубинської революції для американсько-кубинських відносин: Дж. Лівеслі [4], Л. Шульц [5]. Окремо можна виділити дослідження, у яких означена проблема вивчається через персоніфікацію позиції Вашингтону щодо кубинського лідера Ф. Кастро та його режиму: Ф. Бонсал [6], Х. Томас [7]. Втім, у названих роботах перші післяреволюційні місяці взаємин офіційних Вашингтону та Гавани детально не розглядалися.

Незважаючи на актуальність означеної теми, у вітчизняній історіографії майже відсутні роботи, які зачіпають висвітлення ставлення Вашингтону щодо Куби у перші післяреволюційні місяці. Тому, існує необхідність у проведенні більш глибокого аналізу особливостей позиції США щодо Кубі в означений період. Відзначимо, що детальне вивчення подій 1959 р. дозволяє виявити специфіку 
формування політики США у ситуаціях зміни урядів в інших країнах, тож таке дослідження має не тільки науково-історичне, а й практичне значення.

Мета дослідження в рамках даної публікації полягає у спробі проаналізувати ставлення Вашингтону щодо післяреволюційної Куби на початку 1959 р. Вивчення якісних змін у позиції Сполучених Штатів щодо Куби у зазначений період позволить виявити ти чинники, які вплинули на подальше загострення американсько-кубинських відносин.

Історія взаємин між Сполученими Штами та Кубою розпочалася задовго до здобуття останньою державної незалежності. До середини ХХ ст. американськокубинські відносини в цілому характеризувалися як дружні, a їх уряди тісно співпрацювали між собою. Революційні події, які відбулися на острові у 19531959 рр. мали величезний вплив на загострення відносин між країнами, що тривало майже всю другу половину XX та на початку XXI ст. Передумовами до цього стали зміни, що сталися у перші місяці 1959 р. як у позиції Вашингтону щодо дій нового режиму на острові, так і в ставленні уряду Ф. Кастро щодо підходів політики США на Кубі. Для кращого розуміння цих ключових змін слід дати коротку характеристику особливостям реакції Сполучених Штатів на революційні події на острові у 1953 - 1959 рр.

Кубинська революція, яка почалася у липні 1953 р. 3 нападу групи молодих кубинців на чолі 3 Ф. Кастро на казарми Монкади та військову фортецю в Сантьяго-де-Куба і продовжувалася до тих пір, поки повстанці, остаточно не витіснили війська президента Ф. Батісти з острову 1 січня 1959 р., була одним 3 визначальних моментів XX ст. Тому, Сполучені Штати, які були найбільшим інвестором і кредитором Куби, не могли не звернути увагу на революційні виступи у країні.

На початку революції, у 1953 - перший половині 1955 рр. реакція Вашингтону на протистояння повстанців і кубинського уряду була досить передбачувана i обумовлена історичною традицією. Як зазначив американський дослідник Л. Шульц, США були готові підтримувати недемократичні режими у Латинської Америки, такі як диктатура Ф. Батісти, тільки тому, що їхня політика була проамериканською [5, с. 55]. Так, у цій ситуації, президент Д. Ейзенхауер не надавав часу або уваги кубинським справам, делегувавши прийняття рішень департаментам. Ті, у свою чергу, спираючись на традиційні методи підтримки проамериканських режимів у регіоні, надавали дружньому уряду Ф. Батісти політичну i військову допомогу. Вона полягала у наданні Кубі додаткової військової допомоги згідно з двосторонньою угодою [8, с. 67], а також через співпрацю кубинського розвідувального бюро і ЦРУ США [3, с. 36]. До того ж, активною була участь Вашингтона в обезголовленні кубинської опозиції через арешт у США іiі лідера і колишнього президента К. Пріо Сокарса [9]. Причому на офіційному рівні Сполучені Штати дотримуватись політики невтручання у внутрішні справи Куби.

У другій половині 1955 - 1956 рр., незважаючи на збільшення революційної активності на Кубі, Вашингтон продовжив дотримуватися позиції нехтування небезпекою повалення проамериканського режиму Ф. Батісти, бо домінуючою серед американського істеблішменту була думка про те, що загрози американським інтересам на острові немає. Хоча США визнавали серйозність політичного підтексту подій на Кубі, але під постійним тиском 3 боку американського посольства у Гавані продовжували підтримувати політику кубинського уряду. Слід 
зазначити, що у цей період саме американське посольство на острові було тим чинником, яке грало одну із вирішальних ролей у прийняті рішень у кубинському питанні. Посол А. Гарднер i його наступник Е. Сміт, обидва республіканські роялісти, підтримували точку зору Ф. Батісти і не заглиблювалися у причини кубинського революційного руху. Короткозорість послів була також ускладнена відсутністю інтересу до подій на Кубі в адміністрації Д. Ейзенхауера. Роботу американського посольства у ті часи краще за все описала англійська дослідниця Дж. Лівеслі: «Найбільш нетямущими свідками революційної боротьби, що розгорнулася після 1953 р., часто були ті, хто був близький до подій» [4, с. 12].

Під час найбільш гострої фази революції, у грудні 1956 - 1958 рр., ставлення Вашингтону до дій режиму Ф. Батісти, опозиції, а також повстанців, на чолі 3 молодим революціонером Ф. Кастро, було неоднозначним. Але саме в цей період США зрозуміли небезпечність політики суворого нейтралітету для своїх національних інтересів. Американська підтримка дій кубинського уряду значно знизилась через зростаюче невдоволення світовою спільнотою жорсткою i неефективною політикою Ф. Батісти. Це могло підірвати американський авторитет у міжнародних організаціях, а також загрожувало особливим багаторічним американсько-кубинським відносинам. Тому, Сполучені Штати припинили дію угоди про військову допомогу Кубі і скасували поставки зброї кубинській армії. Крім того, через маніпулювання громадською думкою у самих США, серед представників політичних кіл оцінка подій на Кубі загалом та ставлення до фігури iii лідера Ф. Кастро розділилися. Відомий американський дослідник Г. Томас, описуючи ситуацію, яка склалася в уряді США, зазначив іiі суперечливість. 3 одного боку, були урядовці, які вважали, що Ф. Кастро завжди був комуністом, i тому його слід якнайшвидше прибрати. 3 іншого, багато членів американського уряду покладали на Ф. Кастро великі надії і певний час сподівалися, що він може виявитися лібералом [7].

Зміни у ставленні Вашингтону до революційних подій на Кубі стали одним 3 вирішальних чинників, що вплинуло на рішення Ф. Батісти подати у відставку і передати владу військово-цивільної адміністрації. Так, 31 грудня 1958 р. колишній диктатор подав у відставку і, бажаючи уникнути трибуналу, вже наступного дня втік до Домініканської Республіки.

Втім, військово-цивільна адміністрація, яка була створена за підтримки Сполучених Штатів як альтернатива уряду Ф. Батісти, не встигла реалізувати свій політичній потенціал. Вже 1 січня 1959 р., повстанські війська увійшли у Сантьяго, а наступного дня у Гавану. 6 січня у столицю прибув лідер революції Ф. Кастро.

Уряду США довелося обирати між тим, або дозволити молодому революціонеру взяти владу, або відправити на острів американський військовий контингент. Вашингтон обрав перше. Так, 7 січня 1959 р. Сполучені Штати визнали новий кубинський уряд. У Білому домі вважали, що, новий уряд був вільний від комуністичного впливу і мав намір вести дружні відносини зі США [10].

Незважаючи на те що між Сполученими Штатами и Кубою багато років були тісні особливі зв'язки і Вашингтон майже одразу визнав революційний уряд, відносини між країнами різко погіршилися. Але у перші місяці обидві сторони шукали точки дотику i намагались прояснити для себе позицію протилежної сторони. 
Для кращого розуміння ситуації, яка склалося у перші дні існування нової Куби, i розробки загального стратегічного курсу щодо нового уряду - у Вашингтоні збирали інформацію про молодого кубинського лідера і революційну владу. Підтвердженням цього $є$ низка документів.

Так, однією 3 перших була аналітична записка, отримана у Білому домі 13 січня 1959 р. [11]. Вона містила інформацію про політичні погляди Ф. Кастро та його взаємини 3 кубинськими комуністами. Автор записки, спеціальний представник Білого дому, стверджував, що не існує твердої ознаки того, що Ф. Кастро симпатизував комуністам. На думку автора, Ф. Кастро був скоріше націоналістом і дещо соціалістом i, незважаючи на те, що критикував підтримку Сполученими Штатами уряду Ф. Батісти, не міг вважатися особисто ворожим до Вашингтону.

Детальна інформація стосовно характеристики нового кубинського кабінету міністрів, містилася у дипломатичної депеші № 748, відправленої з американського посольства у Гавані 19 січня 1959 р. [12, с. 370-372]. У депеші здійснювався аналіз політичної приналежності кожного з членів кабінету міністрів і прем'єр-міністра Х. Міро Кардона. У висновках акцентувалася увага на те, що до кабінету міністрів входили лише особи, пов'язані 3 рухом «26 липня», групою «Монтесрісті» та партією «Ортодокс», тобто тільки ті, хто під час Кубинської революції був в опозиції до уряду Ф. Батісти.

Політичний настрій кубинського суспільства та його ставлення до Сполучених Штатів у перші дні після революційних подій 1953-1959 рр. досить точно описано у листі консула П. Воллама, який перебував у Сантьяго-де-Кубі, адресованому заступнику директора управління у справах країн Карибського басейну та Мексики Е. Літтлу [13, с. 372-374]. П. Воллам вважав, що результати революції для американсько-кубинських відносин були дещо гіршими, ніж очікувалось. Так, у кубинському суспільстві була поширена думка про те, що саме Сполучені Штати та ї представники винні у застосуванні насильства i бомбардуванні міст, яке було здійснено урядом Ф. Батісти. На думку автора листа, це могло сприяти укріпленню позицій комуністів та інших антиамериканських елементів. Виходячи з цього, автор листа пропонував звернути увагу не стільки на виправдовування i захист американської політики на острові, скільки на інформування кубинської громади про позитивні результати цієї політики.

Таким чином, у зібраній аналітичній інформації наводилася думка про те, що ані нова кубинська влада, ані кубинська громадськість, не були задоволені політикою США щодо Куби, і тому слід було більш уваги приділити цьому аспекту.

3 метою встановлення дружніх зав'язків 3 новим кубинським урядом, американською стороною було проведено низку зустрічей з його представниками. У ході цих зустрічей, було з'ясовано ключові проблеми, які могли б загрожувати відновленню тісних взаємин між Вашингтоном і Гаваною. Так, кубинський державний міністр Р. Аграмонте Пічадо у розмові з радником посольства США на Кубі Д. Бреддоком, звернув увагу останнього на проблему діяльності американських військових місій і преси під час революційних подій 1953 1959 pp., а також на особисті дружні зв'язки посла Е. Сміта 3 колишнім президентом Ф. Батістою, які негативно сприймалися нової владою [14, с. 377]. Крім того, американською стороною визнавалось, що однією з головних проблем у відносинах 3 новим кубинським урядом може бути питання екстрадиції деяких 
політичних біженців режиму Ф. Батісти, які знайшли притулок у США [15, с. 382]. 3'ясувавши глибину можливих американсько-кубинських протиріч, Вашингтон обрав традиційні дипломатичні інструменти їх вирішення.

У Білому домі визнавали, що буде дуже важко підтримувати дружні відносини з новим кубинським урядом без призначення нового посла [16, с. 349]. Тому, для підтвердження своїх дружніх намірів, президент Д. Ейзенхауер призначив Ф. Бонсала, видатного спеціаліста з латиноамериканських справ, новим послом на Кубі. Розуміючи, що на цьому етапі будь-який тиск з боку Сполучених Штатів посилить роль антиамериканських елементів на острові, перед новим послом ставилася мета здійснювати м'який і стабільний вплив на Ф. Кастро i кубинський уряд.

У середині лютого 1959 р., напередодні приїзду Ф. Бонсала у Гавану, ставлення та наміри нового кубинського режиму до Сполучених Штатів все ще перебували у стадії формування. Незважаючи на деякі антиамериканські публічні промови кубинського лідера Ф. Кастро та його прибічників, кубинська влада визнавала, що хороші відносини 3 США $€$ політичною та економічною необхідністю для Куби.

У перші тижні у ранзі посла Ф. Бонсал провів велику аналітичну роботу щодо налагодження ефективної співпраці між Вашингтоном і Гаваною. У результаті, новий посол дійшов висновку, що необхідно зламати стару форму американськокубинської дипломатичної взаємодії й побудувати нові, більш конструктивні відносини 3 новим урядом. Ф. Бонсал був переконаний, що патерналізм, який характеризував відносини між двома країнами ще з 1898 р. став анахронізмом i США необхідно перейти до нового, рівноправного співробітництва з Кубою [17, c. 11-12]. Проте, не всі у Вашингтоні поділяли цю точку зору. Як стверджував американський історик Ж. Бенджамін, більшість посадовців США були впевнені в тому, що сила обставин змусить Ф. Кастро перебувати в межах параметрів традиційних американсько-кубинських відносин. Тобто навіть революційний лідер може бути «навчений правильної поведінки» [18, с. 150].

У квітні 1959 р., після трьох з половиною місяців після перемоги революції, відбувся історичний візит нового кубинського прем'єр-міністра Ф. Кастро до США. Він був неофіційний, на запрошення Американського товариства редакторів газет, але це була можливість для обох сторін краще зрозуміти позиції одна одної у багатьох питаннях.

Слід зазначити, що пропозиція про корисність візиту Ф. Кастро до Сполучених Штатів для американсько-кубинських відносин і для стабілізації ситуації на Кубі розглядалася ще на початку лютого 1959 р., коли в його публічних промовах почали з'являтися приховані антиамериканські заклики. На це у листуванні 3 державним департаментом США звертав увагу радник американського посольства у Гавані Д. Бреддок [19, с. 395]. Він припускав, що візит може розвіяти більшість підозр і забобонів кубинського лідера. Проте, на даному етапі, питання про офіційне запрошення Ф. Кастро до Вашингтону ще не розглядалось. Як пізніше згадував посол Ф. Бонсал, можливо, візит Ф. Кастро до Сполучених Штатів, у поєднанні з взаємним візитом президента Д. Ейзенхауера на острів був би корисним для встановлення сердечних та розумних відносин 3 новою Кубою, але на той момент час для таких візитів ще не прийшов [6, с. 62].

Неофіційний візит лідера кубинської революції до США був сприйнятий у Вашингтоні неоднозначно. 3 одного боку, Ф. Кастро, перебуваючи на посаді 
прем’єр-міністра Куби, проігнорував дипломатичну процедуру і не повідомів про свій намір державні структури тієї країни, яку він запланував відвідати. Тому, Державний департамент США не підтримав офіційним запрошенням візит Ф. Кастро i, враховуючи формальний статус останнього, не планував зустріч на вищому рівні. 3 іншого боку, у Вашингтоні розуміли, що Ф. Кастро, як лідер успішного кубинського революційного руху, деякий час буде ключовою силою в американсько-кубинських відносинах [20, с. 428-430]. Враховуючи це, американською стороною було докладено зусиль для організації зустрічей 3 політиками, представниками економічної еліти США та 3 віце-президентом Р. Ніксоном.

Однак, в ході переговорів Ф. Кастро і його радників 3 американськими представниками, сторони не знайшли взаєморозуміння. Це було пов'язано 3 характером самого переговорного процесу та очікуваннями сторін. 3 огляду на патерналістське ставлення значної частини американських політиків до латиноамериканських країн та їх лідерів, візит Ф. Кастро до Вашингтону був сприйнятий як традиційна форма американсько-кубинської взаємодії - прохання про економічну допомогу для підтримки режиму. Тому, американська сторона була впевнена у результатах переговорів і наполягала на своїх умовах, за якими Куба повинна була залишатися виключно в межах сфери впливу США. Кубинська сторона негативно сприйняла як ставлення Вашингтону до своєї делегації, так i запропоновані ним форми американсько-кубинської взаємодії. Підсумком візиту Ф. Кастро до Сполучених Штатів була впевненість кубинського лідера та його оточення у неможливості конструктивного американсько-кубинського діалогу. Тим самим, була втрачена можливість на побудову нової моделі взаємовідносин між двома країнами.

По поверненню до Куби, Ф. Кастро приступив до проведення серії радикальних соціально-економічних реформ на острові, які зачепили інтереси Сполучених Штатів на острові. Його антиамериканська риторика, радикальна внутрішня політика, співпраця 3 кубинськими комуністами, підтримка революційних рухів за кордоном та зближення з Радянським Союзом сприяли загостренню американсько-кубинських відносин i подальшому розриву дипломатичних відносин між двома країнами. Помічник держсекретаря США по міжнародних відносинах Р. Руботтом так підсумував еволюцію взаємин між Вашингтоном і Гаваною на початку 1959 р.: «Період з січня по березень може бути охарактеризований як період медового місяця. У квітні тенденція до зниження курсу американсько-кубинських відносин була очевидною» [21, с. 742].

Таким чином, на самому початку 1959 р. можна охарактеризувати позицію Вашингтону щодо післяреволюційної Куби як вичікувальну. Незважаючи на те, що Сполучені Штати майже одразу визнали революційний уряд, відносини між країнами почали погіршуватися. Прихильність США до традиційних патерналістських підходів у формуванні своєї політики щодо Куби негативно вплинула на встановлення діалогу 3 новим кубинським урядом, тож спроби налагодити взаєморозуміння, здійснені упродовж перших місяців після революції, виявилися невдалими.

\section{Список використаних джерел та літератури}

1. Dominguez E. United States - Cuban Relations: A Critical History / E. Dominguez, G.Prevost. - Plymouth: Lexington Books, 2008. - 166 p. 
2. Pérez Jr, L. Cuba and the United States: Ties of Singular Intimacy / L. Pérez, Jr. - Athens: The University of Georgia Press, 2003. - $336 \mathrm{p}$.

3. Sanz D. Cuba at a Crossroads the New American Strategy / D. Sanz. - Charleston: BookSurge Publishing, 2009. $-252 \mathrm{p}$.

4. Lievesley G. The Cuban Revolution: Past, Present and Future / G. Lievesley. London : Palgrave Macmillan, $2004-226 \mathrm{p}$.

5. Schoultz L. That Infernal Little Cuban Republic: The United States and the Cuban Revolution / L.Schoultz. - Chapel Hill: University of North Carolina Press, 2009. - 744 p.

6. Bonsal P. Cuba, Castro, and the United States / P.Bonsal. - Pittsburgh: University of Pittsburgh Press, 1971. $-316 \mathrm{p}$.

7. Thomas H. The U.S. and Castro, 1959 - 1962 / H.Thomas // American Heritage. - 1978. Vol. 29, Iss. 6. [Electronic resource] - Mode of Access: http://www.americanheritage.com/content/usand-castro-1959\%E2\%80\%931962?page=show (Last Access: 21th June 2017). - Title from the Screen.

8. Military Assistance Agreement. March 7, 1952 // Treaties in Force. A List of Treaties and Other International Agreements of the United States in Force on January 1, 2013 / The Treaty Affairs Staff, Office of the Legal Adviser, U.S. Department of State. - Washington : United States Government Printing, 2013. $-504 \mathrm{p}$.

9. Explosive State of Cuba. Batista`s position. Strength of opposition. Boom in Venezuela. Evidence of Dictatorship. Army Power. Construction of public Works. Standart of Living. Cuba. Venezuela. Information Report. Sept-Oct. 1954 // The Central Intelligence Agency. [Electronic resource] - Mode of Access: https://www.cia.gov/library/readingroom/docs/CIA-RDP83-00423R0020001600084.pdf (Last Access: 27th August 2017). - Title from the Screen.

10. Memorandum From the Secretary of State to the President. Washington, January 7, 1959 // Eisenhower Library, Project «Clean Up» Records, Cuba. [Electronic resource] - Mode of Access: https://history.state.gov/historicaldocuments/frus1958-60v06/d217 (Last Access: 3th August 2017). Title from the Screen.

11. White House Special Staff Note. Washington, January 13, 1959 // Eisenhower Library, Whitman File, DDE Diaries. [Electronic resource] - Mode of Access: https://history.state.gov/historicaldocuments/frus1958-60v06/d224 (Last Access: 3th August 2017). Title from the Screen.

12. Despatch From the Embassy in Cuba to the Department of State. Havana, January 19, 1959. No. 748 // Foreign Relations of the United States, 1958-1960, Cuba / Ed. Ronald D. Landa. Washington: United States Government Printing Office, 1991. - Vol VI. - 1228 p. [Electronic resource] Mode of Access: https://history.state.gov/historicaldocuments/frus1958-60v06/pg_370 (Last Access: 20th October 2017). - Title from the Screen.

13. Letter From the Consul at Santiago de Cuba (Wollam) to the Deputy Director of the Office of Caribbean and Mexican Affairs (Little). Santiago de Cuba, January 19, 1959 // Foreign Relations of the United States, 1958-1960, Cuba / Ed. Ronald D. Landa. - Washington: United States Government Printing Office, 1991. - Vol VI. - 1228 p. [Electronic resource] - Mode of Access: https://history.state.gov/historicaldocuments/frus1958-60v06/pg_372 (Last Access: 19th October 2017). Title from the Screen.

14. Telegram From the Embassy in Cuba to the Department of State. Havana, January 20, 1959-5 p.m. №864 // Foreign Relations of the United States, 1958-1960, Cuba / Ed. Ronald D. Landa. Washington: United States Government Printing Office, 1991. - Vol VI. - 1228 p. [Electronic resource] Mode of Access: https://history.state.gov/historicaldocuments/frus1958-60v06/pg_377 (Last Access: 20th October 2017). - Title from the Screen.

15. Editorial Note // Foreign Relations of the United States, 1958-1960, Cuba / Ed. R. Landa. Washington: United States Government Printing Office, 1991. - Vol VI. - 1228 p. [Electronic resource] Mode of Access: https://history.state.gov/historicaldocuments/frus1958-60v06/pg_382 (Last Access: 30th October 2017). - Title from the Screen.

16. Memorandum of a Telephone Conversation Between the President and the Secretary of State, Washington, January 9, 1959, 2:56 p.m. // Foreign Relations of the United States, 1958-1960, Cuba / Ed. R. Landa. - Washington: United States Government Printing Office, 1991. - Vol VI. - 1228 p. [Electronic resource] - Mode of Access: https://history.state.gov/historicaldocuments/frus195860v06/pg_349 (Last Access: 27th October 2017). - Title from the Screen. 
17. LeoGrande W. Back Channel to Cuba: The Hidden History of Negotiations between Washington and Havana / W. LeoGrande, P.Kornbluh. - Chapel Hill: The University of North Carolina Press, 2015. $-567 \mathrm{p}$.

18. Benjamin J. Interpreting the U.S. Reaction to the Cuban Revolution, 1959-1960 / J. Benjamin // Cuban Studies. - 1989. - Vol. 19. - P. 145-165.

19. Telegram From the Embassy in Cuba to the Department of State. Havana, February 5, 195911 a.m. № 930 // Foreign Relations of the United States, 1958-1960, Cuba / Ed. R. Landa. - Washington: United States Government Printing Office, 1991. - Vol VI. - 1228 p. [Electronic resource] - Mode of Access: https://history.state.gov/historicaldocuments/frus1958-60v06/pg_395 (Last Access: 20th October 2017). - Title from the Screen.

20. Memorandum From the Assistant Secretary of State for Inter-American Affairs (Rubottom) to the Acting Secretary of State. Washington, March 12, 1959 // Foreign Relations of the United States, 1958-1960, Cuba / Ed. R. Landa. - Washington: United States Government Printing Office, 1991. - Vol VI. $\quad-\quad 1228$ p. [Electronic resource] - Mode of Access: https://history.state.gov/historicaldocuments/frus1958-60v06/pg_428 (Last Access: 22th October 2017). Title from the Screen.

21. Memorandum of Discussion at the $432 \mathrm{~d}$ Meeting of the National Security Council, Washington, January 14, 1960, 9 a.m. // Foreign Relations of the United States, 1958-1960, Cuba / Ed. R. Landa. - Washington: United States Government Printing Office, 1991. - Vol VI. - 1228 p. [Electronic resource] - Mode of Access: https://history.state.gov/historicaldocuments/frus1958-60v06/pg_742 (Last Access:20th October 2017). - Title from the Screen.

\section{References}

1. DOMINGUEZ, E. (2008) United States - Cuban Relations: A Critical History. Plymouth: Lexington Books.

2. PEREZ, L. (2003) Cuba and the United States: Ties of Singular Intimacy. Athens: The University of Georgia Press.

3. SANZ, D. (2009) Cuba at a Crossroads the New American Strategy. Charleston: BookSurge Publishing.

4. LIEVESLEY, G. (2004) The Cuban Revolution: Past, Present and Future. London: Palgrave Macmillan.

5. SCHOULTZ, L. (2009) That Infernal Little Cuban Republic: The United States and the Cuban Revolution. Chapel Hill: University of North Carolina Press. Press.

6. BONSAL, P. (1971) Cuba, Castro, and the United States. Pittsburgh: University of Pittsburgh

7. THOMAS, H. (1978) The U.S. and Castro, 1959 - 1962 American Heritage. [Online] Available from: http://www.americanheritage.com/content/us-and-castro1959\%E2\%80\%931962?page=show [Accessed: $21^{\text {th }}$ June 2017].

8. MILITARY ASSISTANCE AGREEMENT. MARCH 7, 1952 (2013) Treaties in Force. A List of Treaties and Other International Agreements of the United States in Force on January 1, 2013. Washington: United States Government Printing.

9. USA. THE CENTRAL INTELLIGANCE AGENCY (1954) Explosive State of Cuba. Batista`s position. Strength of opposition/Boom in Venezuela. Evidence of Dictatorship. Army Power. Construction of public Works. Standart of Living. Cuba. Venezuela. Information Report. Sept-Oct. The Central Intelligence Agency. Official website of the Central Intelligence Agency [Online]. Available from: https://www.cia.gov/library/readingroom/docs/CIA-RDP83-00423R002000160008-4.pdf [Accessed: $27^{\text {th }}$ August 2017].

10. MEMORANDUM FROM THE SECRETARY OF STATE TO THE PRESIDENT (1959)

Eisenhower Library, Project «Clean Up» Records, Cuba. [Online]. Available from: https://history.state.gov/historicaldocuments/frus1958-60v06/d217 [Accessed: $3^{\text {th }}$ August 2017].

11. WHITE HOUSE SPESIAL STAFF NOTE. WASHINGTON (1959) Eisenhower Library, Whitman File, DDE Diaries. [Online]. Available from: https://history.state.gov/historicaldocuments/frus1958-60v06/d224 [Accessed: $3^{\text {th }}$ August 2017].

12. LANDA, R. (ed.) (1991) Despatch from the Embassy in Cuba to the Department of, State Havana, January 19, 1959. Foreign Relations of the United States, 1958-1960, Cuba. VI. Washington: United States Government Printing Office. [Online]. Available from: https://history.state.gov/historicaldocuments/frus1958-60v06/pg_370 [Accessed: 20 ${ }^{\text {th }}$ October 2017]. 
13. LANDA, R. (ed.) (1991) Letter from the Council at Santiago de Cuba (Wollam) to the Deputy Director of the Office of Carribean and Mexican Affairs (Little) Santiago de Cuba, January 19, 1959. Foreign Relations of the United States, 1958-1960, Cuba. VI. Washington: United States Government Printing Office. [Online]. Available from: https://history.state.gov/historicaldocuments/frus195860v06/pg_372 [Accessed: $19^{\text {th }}$ October 2017].

14. LANDA, R. (ed.) (1991) Telegram from the Embassy in Cuba to the Department of, State, Havana, January 20, 1959. 5 p.m. Foreign Relations of the United States, 1958-1960, Cuba. VI. Washington: United States Government Printing Office. [Online]. Available from: https://history.state.gov/historicaldocuments/frus1958-60v06/pg_377 [Accessed: $20^{\text {th }}$ October 2017].

15. LANDA, R. (ed.) (1991) Editorial Note. Foreign Relations of the United States, 1958-1960, Cuba. VI. Washington: United States Government Printing Office. [Online]. Available from: https://history.state.gov/historicaldocuments/frus1958-60v06/pg_382 [Accessed: 30 ${ }^{\text {th }}$ October 2017].

16. LANDA, R. (ed.) (1991) Memorandum of a Telephone Conversation between the President and Secretary of State. Washington, January 9, 1959, 2:56 p.m. Foreign Relations of the United States, 1958-1960, Cuba. VI. Washington: United States Government Printing Office. [Online]. Available from: https://history.state.gov/historicaldocuments/frus1958-60v06/pg_349 [Accessed: 27 ${ }^{\text {th }}$ October 2017].

17. LEOGRANDE, W. (2015) Back Channel to Cuba: The Hidden History of Negotiations between Washington and Havana. Chapel Hill: The University of North Carolina Press.

18. BENJAMIN, J. (1989) Interpreting the U.S. Reaction to the Cuban Revolution, 1959-1960 Cuban Studies. 19. P. 145-165.

19. LANDA, R. (ed.) (1991) Telegram from the Embassy in Cuba to the Department of, State, Havana, February 5, 1959-11 a.m. Foreign Relations of the United States, 1958-1960, Cuba. VI. Washington: United States Government Printing Office. [Online]. Available from: https://history.state.gov/historicaldocuments/frus1958-60v06/pg_395 [Accessed: $20^{\text {th }}$ October 2017].

20. LANDA, R. (ed.) (1991) Memorandum from the Assistant Secretary of State for InterAmerican Affairs (Rubbotom) to the Acting Secretary of State. Washington, March 12, 1959. Foreign Relations of the United States, 1958-1960, Cuba. VI. Washington: United States Government Printing Office. [Online]. Available from: https://history.state.gov/historicaldocuments/frus1958-60v06/pg_428 [Accessed: 22 ${ }^{\text {th }}$ October 2017].

21. LANDA, R. (ed.) (1991) Memorandum of Discussion at the 432D Meeting of the National Security Council. Washington, January 14, 1960, 9 a.m. Foreign Relations of the United States, 19581960, Cuba. VI. Washington: United States Government Printing Office. [Online]. Available from: https://history.state.gov/historicaldocuments/frus1958-60v06/pg_742 [Accessed: 20 $0^{\text {th }}$ October 2017].

Надійшла до редколегії 14.03.2018

Kateryna Kasatkina, post-graduate student, Zaporizhzhya National University.

\title{
WASHINGTON'S POSITION TOWARDS POST-REVOLUTIONARY CUBA (EARLY 1959)
}

\begin{abstract}
The article attempts to analyze the official Washington's attitude towards the post-revolutionary Cuba in the first months of the 1959. Generally, the Cuban revolutionary events of 1953-1959 which greatly influenced the American perception of the new Cuban government have been described. Main issues threatening the restoration of the U.S.-Cuban relations in the period investigated have been analyzed. The role of diplomatic factors as foreign policy instruments has been considered. The analytical work of the American diplomats on establishing of effective cooperation between Washington and Havana in the first months of the 1959 has been described. The F. Castro's role in the capacity of a leader of the Cuban revolutionary movement, as well as the motive forces in further American-Cuban relations have been unfolded.

It is concluded that the official Washington's position towards the post-revolutionary Cuba in the first months of the 1959 may be characterized as a "wait and see" strategy. However, in general, the United States' commitment to the traditional paternalistic approaches in the American policy towards Cuba has had some negative effect upon the establishment of a
\end{abstract}


dialogue with the new Cuban government. Therefore, in the first months after the Cuban Revolution, two countries have failed to reach mutual understanding.

Key words: United States, Cuba, Cuban Revolution, diplomacy, F. Castro.

УДК 94(7/8)

Павло Кряжев,

кандидат педагогічних наук

\title{
МІСІЯ КРІСТОВАМА ЖАКІША НАПЕРЕДОДНІ ЗАПОЧАТКУВАННЯ СИСТЕМАТИЧНОЇ КОЛОНІЗАЦЇ̈ БРАЗИЛІЇ ПОРТУГАЛЬЦЯМИ
}

\begin{abstract}
Анотація. У статті розглянуто місію португальського капітана-мора Крістовама Жакіша в контексті започаткування систематичної колонізачії Бразилії португальиями у 1530 р. Звернено увагу на документи, щзо висвітлюють перебіг військово-інспекиійних ескадр під командуванням Жакіша і заснування португальського форпосту в Південній Америці - факторії "Сітіо-ду-Марку». У статті з'ясовано, щуо організація згаданих військово-інспекційних експедииій до берегів Бразилії була вимученою реакиією португальської корони на загрозливі спроби франиузьких корсарів закріпитися на ї̈ березі. Іншими словами, ескадри Крістовама Жакіша були покликані нейтралізувати загрозу втрати короною Португалії нововідкритої землі в Південній Атлантиці. В изьому контексті у статті зазначено, що франиузькі ескадри корсарів із Бретані $і$ Нормандіі почали свої плавання у напрямку Бразилї, починаючи з 1503 р., і досягли найбільшої своєї активності в 20-х рр. XVI cm. Перша подібна експедиція під командуванням адмірала Гонневіля розпочалася 24 червня 1503 р., коли із гавані Онфлер відбув корабель «Еspoir de Honfleur». Наголошено на тій обставині, щзо місія капітана-мора Крістовама Жакіша полягала у підготовиі надійного підгрунтя для ініціювання королем Жоао III першої колонізаційної експедииї до Бразилії під командуванням капітана-мора Мартіма Афонси де Соузи.
\end{abstract}

Ключові слова: Бразилія, колонізація, військово-інспекиійна ескадра, капітан-мор, факторія, пау-бразіл.

Місія португальського капітана-мора Крістовама Жакіша, як головнокомандувача декількох військово-інспекційних ескадр до берегів Бразилії протягом 1516-1528 pp., є однією 3 малодосліджених тем в бразильській і зарубіжній історіографії. Серед праць, у яких аналізувалися причини організації експедицій Жакіша, їхній перебіг і наслідки, слід назвати колективні дослідження португальських істориків Ф.М. Естевеша Перейри, А. Байяо і Е.С. Мелейри Діаша [1, с. 361-364; 2, с. 59-94]. На жаль, для грунтовного дослідження вказаної проблеми існує не так багато документів i першоджерел. Архівні матеріали висвітлюють перебіг експедицій Жакіша досить побіжно.

Користуючись наявними документами i першоджерелами, які вперше вводяться у науковий обіг в українській історичній науці, спробуємо з'ясувати обставини організації і значення військово-інспекційних експедицій капітана-мора Крістовама Жакіша для започаткування систематичної колонізації Бразилії португальцями у 1530 р.

Коли минуло перше десятиліття XVI ст. первинної розвідки берегів Бразилії низкою португальських експедицій, у подальшому фіксуються перші спроби португальців закріпитися на нововідкритій землі шляхом заснування укріплених торговельних факторій з метою забезпечення експорту цінної породи червоного 